This manuscript has been accepted for publication in the Journal of Nuclear Materials. Please note that, despite having undergone peer-review, the manuscript has yet to be formally published. Printed version may have slightly different content. The final version of this manuscript will be available via the 'Peer-reviewed Publication DOI' link. Please feel free to contact the corresponding author. Any feedback will be greatly appreciated. 


\section{Effect of solution chemistry on the iodine release from iodoapatite in aqueous environments}

2 Zelong Zhang ${ }^{\dagger *}$, Léa Gustin ${ }^{\ddagger 1}$, Weiwei Xie ${ }^{\ddagger}$, Jie Lian ${ }^{\S}$, Kalliat T. Valsaraj", and Jianwei Wang ${ }^{\dagger, \perp}$

$3 \dagger^{\dagger}$ Department of Geology and Geophysics, Louisiana State University, Baton Rouge, Louisiana

470803 United States

$5 \quad$ Department of Chemistry, Louisiana State University, Baton Rouge, Louisiana 70803 United

6 States

$7 \quad \S$ Department of Mechanical, Aerospace, and Nuclear Engineering, Rensselaer Polytechnic

8 Institute, 110 Eighth Street, Troy, New York 12180, United States

9 II Cain Department of Chemical Engineering, Louisiana State University, Baton Rouge,

10 Louisiana 70803 United States

$11 \perp$ Center for Computation and Technology, Louisiana State University, Baton Rouge, Louisiana

1270803 , United States

$13 \quad *$ Corresponding to zelongz@1su.edu

${ }^{1}$ Current address: Department of Chemistry, University of Wisconsin-Madison, Madison, Wisconsin 53706, United States 


\section{Highlights}

- First study on the effect of aqueous ions on the degradation of waste form for I-129

- First summary on probable iodine release pathways in various aqueous environments

- Accelerated iodine release by enhanced ion-exchange, basicity or acidity, and ionic strength

- Discovered secondary phase vanadinite $\mathrm{Pb}_{5}\left(\mathrm{VO}_{4}\right)_{3} \mathrm{Cl}$ and hydroxylvanadinite $\mathrm{Pb}_{5}\left(\mathrm{VO}_{4}\right)_{3} \mathrm{OH}$

- Low ionic content and neutral $\mathrm{pH}$ are vital to the disposal safety of nuclear waste 


\section{Abstract}

25 To ensure the safe disposal of nuclear waste, understanding the release process of radionuclides

26 retained in the nuclear waste forms is of vital importance. Iodoapatite $\mathrm{Pb}_{9.85}\left(\mathrm{VO}_{4}\right)_{6} \mathrm{I}_{1.7}$, a potential

27 waste form for iodine-129, was selected as a model system for ceramic waste forms in this study

28 to understand the effect of aqueous species on iodine release. Semi-dynamic leaching tests were

29 conducted on bulk samples in cap-sealed Teflon vessels with $0.1 \mathrm{~mol} / \mathrm{L} \mathrm{NaCl}, \mathrm{Na}_{2} \mathrm{CO}_{3}, \mathrm{Na}_{3} \mathrm{PO}_{4}$,

30 and $\mathrm{Na}_{2} \mathrm{SO}_{4}$ solutions under $90^{\circ} \mathrm{C}$, fixed sample surface area to solution volume ratio of $5 / \mathrm{m}$,

31 and periodic replacement of leaching solutions. The reacted solutions were then analyzed by

32 Inductively Coupled Plasma-Mass Spectrometry and Inductively Coupled Plasma-Optical

33 Emission Spectrometry; the leached surfaces were characterized by X-ray diffraction, scanning

34 electron microscopy, and infrared spectroscopy. The result shows that, compared to deionized

35 water, the ion-rich solutions enhanced the iodine release as a result of the increased ionic

36 strength, reduced activity coefficient of dissolved species, and increased solution $\mathrm{pH}$. Surface

37 reactions can lead to the formations of secondary phases by ion-exchange and precipitation.

38 These findings suggest that an ion-rich environment in the geological repository can be

39 detrimental to the disposal safety of the nuclear waste form. 


\section{Introduction}

41 Nuclear energy is emission-free. The deployment of nuclear energy is motivated by the

42 pressing demand to mitigate climate change. ${ }^{1}$ Sustainable development of the nuclear energy

43 requires concrete plans to safely dispose radionuclides waste generated by nuclear fission. ${ }^{2}$

44 Among those radionuclides, iodine-129 is particularly challenging to handle due to its long half-

45 life (15.7 million years), high yield ( $0.7 \%$ yield per fission of uranium-235) ${ }^{3}$ and weak interactions with common materials in repository environments such as engineering barrier and

47 rock in geology formation. ${ }^{4,5}$ Iodide $\left(\mathrm{I}^{-}\right)$is the most stable form of iodine in an environment with

$48 \mathrm{pH}$ and redox potential typically found in nature. ${ }^{6-8}$ Under highly oxidizing conditions, iodide can be oxidized to iodine $\left(\mathrm{I}_{2}\right)$ and/or iodate $\left(\mathrm{IO}_{3}{ }^{-}\right)$. All these iodine species are highly mobile in

50 nature given their high volatility and or high solubility. ${ }^{9,10}$ Iodine, as an essential element for

51 human health, can accumulate in human bodies. ${ }^{11}$ For a healthy adult, $30 \%$ of the total iodine,

52 approximately $15-20 \mathrm{mg}$, is concentrated in the thyroid gland. ${ }^{12}$ Chronical radiation from iodine-

53129 beta decay can induce cancer to the thyroid follicular cells. ${ }^{11}$ Therefore, iodine-129 is a

54 primary contributor of the radiation dosage when analyzing the safety of disposal environments. ${ }^{4}$

55 The immobilization of iodine-129 is one of the critical research subjects for nuclear waste

56 management. ${ }^{4,13-18}$

57 The most probable scenarios that compromise nuclear waste forms in a repository

58 environment are the contact with aqueous solutions. ${ }^{19,20}$ In a typical repository, nuclear waste

59 forms are packed into corrosion resistant metallic canisters underground. ${ }^{21}$ Canister corrosion

60 and degradation are anticipated to be the result of corrodents carried by groundwater. ${ }^{22}$ Through

61 infiltration and percolation of precipitation and groundwater aquifer, water can reach the

62 canisters and supply corrodents to react with the canister material. Upon the breaching of the 
63 canister, the waste forms are exposed to an aqueous environment. Owing to the long half-life of 64 iodine-129, it is crucial to predict the long-term chemical durability of iodine waste forms. To 65 enable such prediction, it is necessary to obtain a fundamental understanding of corrosion 66 mechanisms of waste forms and how iodine in the host material is released in various solutions 67 that may occur under repository conditions.

Several waste form materials including glass, ceramics, glass-ceramics, cement, and composite have been proposed to immobilize iodine. ${ }^{18,23}$ These waste forms immobilize iodine 70 via two major mechanisms: encapsulation and incorporation. To encapsulate iodine, the host 71 matrices need to contain iodine in a designated phase different from the host material. One 72 example is zeolite structure, in which iodine-bearing phases can be adsorbed on zeolite's 73 framework. ${ }^{17,24}$ Iodine can also be incorporated as a compositional element into the host matrix 74 structure through chemical bonding, such as iodoapatite $\mathrm{Pb}_{5}\left(\mathrm{VO}_{4}\right)_{3} \mathrm{I}$ and sodalite $75 \mathrm{Na}_{4}\left(\mathrm{AlSiO}_{4}\right)_{3} \mathrm{I}^{13,25-27}$

The difficulty to study the durability of different waste forms varies on a case-by-case basis.

77 It is particularly challenging to evaluate the encapsulation waste forms due to the complexity of 78 multi-phase and microstructures. On the other hand, characterizing the corrosion mechanism can 79 be relatively straightforward for single-phase crystal waste forms which have well-defined crystal structures and simple microstructures. Based on the simplicity of its crystal structure and 81 microstructure, iodoapatite is chosen in this study as the model system of ceramic waste forms 82 that can incorporate radionuclides. In addition, apatite ceramics is a promising material due to its 83 thermal, mechanical, and chemical stability. ${ }^{13,25,28,29}$ These advantages are also demonstrated in 84 nature as apatite has been found as a retention matrix for actinides and fission products in natural 85 fission reactors at Franceville basin in Africa. ${ }^{22,30}$ 
Several chemical durability tests have been performed on single-phase crystal waste forms.

87 Uno et al. in 2001 conducted soxhlet leach method on apatite $\mathrm{Pb}_{10}\left(\mathrm{VO}_{4}\right)_{6} \mathrm{I}_{2} \cdot{ }^{31}$ Soxhlet leach method is designed to maximize the number of leachable constituents in leachant by allowing a 89 continuous contact between the waste and recycling leachant in a closed system. ${ }^{32}$ The iodine release rate, $3.98 \times 10^{-5} \mathrm{~g} \cdot \mathrm{cm}^{-2} \cdot \mathrm{d}^{-1}$, was reported. ${ }^{31}$ Guy et al. in 2002 studied apatite

$91 \mathrm{~Pb}_{10}\left(\mathrm{VO}_{4}\right)_{4.8}\left(\mathrm{PO}_{4}\right)_{1.2} \mathrm{I}_{2}$ dissolution in aqueous solutions. ${ }^{33}$ The resulting data shows that iodine 92 release was incongruent and exhibited dependency on temperature and $\mathrm{pH}$. They also discovered 93 a secondary phase, lead vanado-phosphate, precipitated at the sample surface. Zhang et al. in 942007 performed static leaching test on $\mathrm{Pb}_{5}\left(\mathrm{VO}_{4}\right)_{3} \mathrm{I}$ powder in a basic $\mathrm{KOH} / \mathrm{KHCO}_{3}$ buffer solution. ${ }^{34}$ Spectroscopic evidences show that $\mathrm{OH}^{-}$and $\mathrm{CO}_{3}{ }^{2-}$ can substitute $\mathrm{I}^{-}$and $\mathrm{VO}_{4}{ }^{3-}$ in 96 apatite. Maddrell et al. in 2014 conducted static leach tests on crushed powder iodide sodalite $97 \mathrm{Na}_{4}\left(\mathrm{AlSiO}_{4}\right)_{3} \mathrm{I}$ in $\mathrm{KOH} / \mathrm{KHCO}_{3}$ buffer solutions. ${ }^{26}$ The result suggests a congruent dissolution. ${ }^{26}$ 98 Three leaching static experiments with durations of 3, 7, and 14 days exhibited a logarithmic 99 increase of iodine release. More recently, in 2017 Coulon et al. applied static leaching technique to study the iodate-substituted hydroxyapatite in deionized water and groundwater. ${ }^{35}$ They 101 reported that the iodine release is controlled by congruent dissolution under unsaturated 102 conditions and controlled by diffusion through ion exchange under saturated condition. 103 Interestingly, when groundwater was used as leachant, secondary phase hydroxyapatite 104 precipitated on the sample surface. Based on these studies, static leach test is a preferable method 105 to study the waste form durability due to the following reasons: 1) its simple procedure can 106 accommodate a wide range of test conditions; 2) the resultant data can be used to interpret the

107 release mechanism. ${ }^{36}$ Static leaching method assumes that the solution feedback is negligible, 108 which is valid under conditions of sufficiently low surface to volume ratio. ${ }^{36}$ However, the 
solution feedback can gradually increase over time in a static leaching experiment. In cases where the solution is oversaturated for phases of low solubility, secondary phases can precipitate at the leached surface. Therefore, it can be problematic to use data from static leaching tests to predict waste form behavior in a repository environment. ${ }^{37}$ To address the issues of solution feedback, a semi-dynamic leaching method was implemented by Zhang et al. in 2018 to quantify the processes involved in the iodine release of an iodine-bearing apatite. ${ }^{29}$ In their experiment, deionized water solutions, as the leachant, were replaced periodically to minimize the solution feedback. They demonstrated that iodine released from apatite is driven by short-term diffusion and long-term matrix dissolution. This semi-dynamic approach was employed to produce essential datasets to parameterize a mechanistic model suitable for predicting the kinetics of iodine release under different conditions. ${ }^{37}$

Since the aqueous systems in natural environment contain a variety of dissolved species, it is necessary to understand how these aqueous species affect the iodine release from iodine waste forms in an aqueous environment. For instance, the iodine release from apatite structured materials can be enhanced by rapid substitution of halogen element ${ }^{38-41}$ or inhibited by precipitation of secondary phase. ${ }^{33,35,37}$ In this study, we conducted semi-dynamic leach tests on single phase crystal ceramics of iodoapatite in $0.1 \mathrm{~mol} / \mathrm{L} \mathrm{NaCl}, \mathrm{Na}_{2} \mathrm{CO}_{3}, \mathrm{Na}_{3} \mathrm{PO}_{4}$ and $\mathrm{Na}_{2} \mathrm{SO}_{4}$ solutions. The goal is to examine the impact of the solution chemistry on the kinetics of iodoapatite dissolution. We hypothesized that dissolved aqueous species, via ion exchange and precipitation, can substantially impact the dissolution kinetics; this effect should highly depend on the chemistry of the aqueous species and the surface reactions of specific phases. The finding of this study is expected to provide important insight into the long-term performance of iodine waste forms and guidance to improve the disposal safety of nuclear waste. 


\section{Experimental}

\subsection{Materials and methods}

Our samples, obtained from previous studies, ${ }^{25}$ were dense ceramic chips in quadrilateral shape: $4.7-10.3$ millimeter long by $1.1-1.8$ millimeter thick with a chemical composition of $\mathrm{Pb}_{9.85}\left(\mathrm{VO}_{4}\right)_{6} \mathrm{I}_{1.7}$ according to the EDS and X-ray diffraction refinement, as shown in Figs. 1, 2 and 4. The iodoapatite samples were synthesized by using high energy ball milling (HEBM) and spark plasma sintering (SPS) techniques. Sample surfaces were polished by 4000 -grit sandpaper on a mechanical polishing wheel lubricated with ethanol. Details of the synthesis and characterization of these samples were reported previously in separate publications. ${ }^{25,29,37}$

The leaching method was adopted from ASTM C1308 standard test, as described in the previous study ${ }^{29,37}$. Four parallel experiments were conducted simultaneously for 14 days in four different leaching solutions: $0.1 \mathrm{~mol} / \mathrm{L} \mathrm{NaCl}, 0.1 \mathrm{~mol} / \mathrm{L} \mathrm{Na}_{2} \mathrm{CO}_{3}, 0.1 \mathrm{~mol} / \mathrm{L}$ $\mathrm{Na}_{3} \mathrm{PO}_{4}$, and $0.1 \mathrm{~mol} / \mathrm{L} \mathrm{Na}_{2} \mathrm{SO}_{4}$. Sample surface area $\left(\mathrm{m}^{2}\right)$ to solution volume $\left(\mathrm{m}^{3}\right)$ ratios $(\mathrm{S} / \mathrm{V})$ of all four tests were fixed and maintained at $5 / \mathrm{m}$. The leached solutions were replaced every 24 hours. All reactor vessels were weighed before and after each interval to monitor the solution losses which were within $0.5 \%$ of the initial solution mass. In addition, a control test was conducted in deionized water under identical conditions for 7 days using the same protocol. All samples after leaching experiments were collected, rinsed by deionized water and ethanol, and air-dried.

\subsection{Characterization}


The elements of interest in the leachate solutions are I, Pb, and $\mathrm{V}$. The leached 154 solutions, depending on the solution chemistry, were analyzed by Inductively Coupled 155 Plasma-Mass Spectrometry (ICP-MS, PerkinElmer Elan 9000) and/or Inductively156 Coupled Plasma-Optical Emission Spectrometry (ICP-OES, SPECTRO Ametek Spectro 157 ARCOS). Two standard solutions from Inorganic Ventures were used in the solution 158 analysis: 1) $1.001 \pm 0.007 \mu \mathrm{g} / \mathrm{mL}$ iodide in $\mathrm{H}_{2} \mathrm{O}$ solution and 2) $1.000 \pm 0.007 \mu \mathrm{g} / \mathrm{mL}$ 159 lead and $1.000 \pm 0.006 \mu \mathrm{g} / \mathrm{mL}$ vanadium in $1 \% \mathrm{HNO}_{3}$ solution. Chemical properties of 160 solution at equilibrium state such as $\mathrm{pH}$, ionic strength, speciation, and activity were 161 calculated by Visual MINTEQ package.

Samples were characterized by Scanning Electron Microscopy (SEM), Infrared 163 spectroscopy (IR), and X-ray diffraction spectroscopy (XRD). SEM images were taken by

164 a FEI Quanta SEM system with FEI Versa 3D DualBeam. Infrared spectroscopy was 165 performed on a Thermo Nicolet Continuum Infrared Microscope under Specular 166 Reflection mode and transmission mode with a fixed incident angle and an aperture area 167 of 10 by $10 \mu \mathrm{m}$ covering 4000 to $650 \mathrm{~cm}^{-1}$ at a spectral resolution of $2 \mathrm{~cm}^{-1}$. XRD data 168 were collected from PANalytical Empyrean X-Ray Diffractometer equipped with 169 monochromated $\mathrm{Cu}-\mathrm{K} \alpha$ radiation $(\lambda=1.5406 \AA)$, operated at $45 \mathrm{kV}, 40 \mathrm{~mA}$, a step size of 170 $0.026^{\circ}$, and a scanning range from 5 to $100^{\circ}$.

171 The crystal structures were refined by Le Bail algorithm using Jana2006 program. ${ }^{42}$ 172 All parameters were refined by the least-squares method. The pseudo-Voigt function was 173 used as the peak profile function. Structural parameters of $\mathrm{Pb} 9.85\left(\mathrm{VO}_{4}\right)_{6} \mathrm{I}_{1.7}$ measured by 174 Audubert et al. were used as initial input (hexagonal, space group P63/m, a = b = 10.422 175 $\left.\AA, c=7.467 \AA, \alpha=\beta=90^{\circ} ; \gamma=120^{\circ}\right) .{ }^{43}$ 


\section{Results}

\subsection{Leached surface characterization by SEM/EDS}

In Fig. 1 (a-c), no changes observable by naked eyes occurred on the surfaces of samples leached by $\mathrm{NaCl}$ and $\mathrm{NaSO}_{4}$ solutions for 14 days, whereas white layers were gradually formed on the sample surfaces leached by $\mathrm{Na}_{2} \mathrm{CO}_{3}$ and $\mathrm{Na}_{3} \mathrm{PO}_{4}$ solutions within the first week of the experiments. The SEM images in Fig. 1 (d-i) show that the surface alterations on samples leached by $\mathrm{NaCl}$ and $\mathrm{Na}_{2} \mathrm{SO}_{4}$ solutions were moderate, similar to the water leached surface. However, samples leached by $\mathrm{Na}_{2} \mathrm{CO}_{3}$ and $\mathrm{Na}_{3} \mathrm{PO}_{4}$ solutions demonstrated significant surface corrosion and possible formation of new phases. The surface leached by $\mathrm{Na}_{2} \mathrm{CO}_{3}$ exhibited large grains, while congregated structures of similar size appeared on the surface leached by $\mathrm{Na}_{3} \mathrm{PO}_{4}$.

According to EDS analysis, the surface chemical compositions in Fig. 2 indicate considerable changes between the leached samples and the pristine one. The key features of EDS spectrum of pristine iodoapatite are: a carbon peak at $0.3 \mathrm{keV}$ from background (carbon tape), an oxygen peak at $0.5 \mathrm{keV}$, a broad $\mathrm{Pb}$ band from 2.34 to $2.45 \mathrm{keV}$ shouldered with two small $\mathrm{Pb}$ peaks at 1.8 and $2.6 \mathrm{keV}$, three iodine peaks at $3.9,4.2$, and $4.5 \mathrm{keV}$, and vanadium peaks at 4.9 and $5.4 \mathrm{keV}$. Overall, the iodine peaks at $3.94 \mathrm{keV}$ are nearly diminished in the EDS spectra of all four leached surfaces. The samples leached by $\mathrm{NaCl}$ and $\mathrm{Na}_{3} \mathrm{PO}_{4}$ exhibited a substantial amount of chloride and phosphorus signals at 2.62 and $2.01 \mathrm{keV}$, respectively. On the sample leached by $\mathrm{NaCl}$, the $\mathrm{Pb}$ peak at $2.62 \mathrm{keV}$ is comparable to the $\mathrm{Pb}$ peak at $1.8 \mathrm{keV}$, while the $2.62 \mathrm{keV}$ peaks of the rest samples are much weaker than their corresponding $1.8 \mathrm{keV}$ peaks. Carbon signal at 0.27 
$198 \mathrm{keV}$ from $\mathrm{Na}_{2} \mathrm{CO}_{3}$ leached sample cannot be properly quantified due to the background 199 interference from carbon tape and the graphite impurity introduced during sample 200 synthesis. Sulfur EDS peak at $2.31 \mathrm{keV}$ overlaps with the broad central peak of $\mathrm{Pb}$ at 2.34 $201 \mathrm{keV} . \mathrm{Na}_{2} \mathrm{SO}_{4}$ leached surface exhibited no sulfur peak near $2.3 \mathrm{keV}$ given the 202 resemblance of the band shape between the sample leached by $\mathrm{Na}_{2} \mathrm{SO}_{4}$ and the rest. We 203 noticed variations of carbon and oxygen EDS signals among these samples which were 204 induced by the instrumentation settings such as sample orientation and beam parameters. 205 Therefore, carbon and oxygen were not considered in the EDS analysis.

\subsection{Leached surface characterization by IR analysis}

The IR spectroscopy results are listed in Fig. 3. All these four samples yielded two main peaks near 750 and $890 \mathrm{~cm}^{-1}$, which are attributed to V-O bond. ${ }^{34}$ Pristine 209 iodoapatite and samples leached by water, $\mathrm{Na}_{2} \mathrm{SO}_{4}$, and $\mathrm{NaCl}$ showed nearly identical spectra. Surfaces leached by $\mathrm{Na}_{2} \mathrm{CO}_{3}$ and $\mathrm{Na}_{3} \mathrm{PO}_{4}$ exhibited position shifts of these two V-O peaks to the region of 700 to $900 \mathrm{~cm}^{-1}$ and multiple new bands. Sample leached by

$212 \mathrm{Na}_{2} \mathrm{CO}_{3}$ yielded sharp bands near 785, 890, 960, 1200, and $1450 \mathrm{~cm}^{-1}$, in which the broad

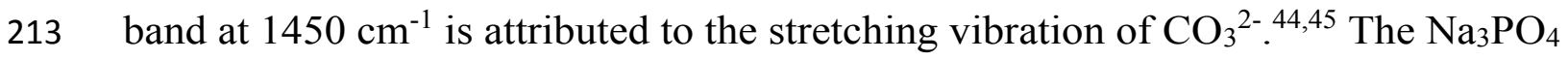

214 leached surface generated IR peaks near 785, 870, 950, 1110, 1420, 1800, and $2200 \mathrm{~cm}^{-1}$,

215 in which some can be assigned to the $\mathrm{PO}_{4}{ }^{3-}\left(\right.$ e.g. $\left.v_{1}-950 \mathrm{~cm}^{-1}, v_{3}-1100 \mathrm{~cm}^{-1}\right){ }^{44}$

216 Interestingly, both $\mathrm{CO}_{3}{ }^{2-}$ and $\mathrm{PO}_{4}^{3-}$ leached surfaces showed visible $\mathrm{OH}^{-}$stretching

217 vibration near $3500 \mathrm{~cm}^{-1},{ }^{34,44}$ which also occurred on water leached surface under IR 218 transmission mode. ${ }^{29}$ 
The XRD data are shown in Fig. 4. All these leached samples demonstrated

221

222

223

224

225

226

227

228

229

230

231

232

233

234

235

236

237

238

239

240 substantial differences compared to the pristine sample. Based on the XRD pattern, these leached samples can be categorized into two groups: I) surfaces leached by $\mathrm{NaCl}$ and $\mathrm{Na}_{2} \mathrm{SO}_{4}$ solutions, the pristine, and water leached sample; II) surfaces leached by $\mathrm{Na}_{2} \mathrm{CO}_{3}$ and $\mathrm{Na}_{3} \mathrm{PO}_{4}$ solutions, which were similar to the standard hydroxylvanadinite. The XRD patterns of Group I are alike, which indicates no substantial structural changes compared to the pristine. The XRD patterns of Group II display enhanced peak splitting between $25^{\circ}$ and $28^{\circ}$. The original peak splitting of the pristine sample reflects the apatite structure deformation which accommodates the relatively large iodide incorporated in the apatite framework. The peak splitting of $\mathrm{Na}_{2} \mathrm{SO}_{4}$ leached surface is slightly enhanced, compared to the pristine, but is weaker than the water leached sample. Interestingly, $\mathrm{NaCl}$ leached surface yielded a diminished splitting at $26^{\circ}$ and a new peak occurred at $29^{\circ}$, later identified as $1 \overline{3} 1$ shown in Fig. 5. The Full Width at Half Maximum (FWHM) of XRD from $\mathrm{NaCl}$ leached surface was considerably broadened to $\sim 0.4^{\circ}$ compared to $\sim 0.2^{\circ}$ from other samples, which may be attributed to the peak overlapping resulting from the presence of a secondary phase. Both $\mathrm{Na}_{2} \mathrm{CO}_{3}$ and $\mathrm{Na}_{3} \mathrm{PO}_{4}$ leached samples exhibited nearly identical XRD pattern, resembling the pattern of standard hydroxylvanadinite $\mathrm{Pb}_{10}\left(\mathrm{VO}_{4}\right)_{6}(\mathrm{OH})_{2}$. The two highest bands on $\mathrm{Pb}_{10}\left(\mathrm{VO}_{4}\right)_{6}(\mathrm{OH})_{2}$ standard are 112 and $1 \overline{3} 1$ with an order of intensity $I_{112}<I_{1 \overline{3} 1}$. Same bands 112 and $1 \overline{3} 1$ also have the highest intensity on $\mathrm{Na}_{2} \mathrm{CO}_{3}$ and $\mathrm{Na}_{3} \mathrm{PO}_{4}$ leached samples, however, the intensity of 112 is higher than that of $1 \overline{3} 1, I_{112}>I_{1 \overline{3} 1}$.

The Le Bail method was applied to obtain structural information from the XRD data. Table 1 compares the refined lattice parameters between sample surfaces of different 
243 conditions and standards. No noticeable changes occurred in the crystal structures of

244 samples leached by deionized water and $\mathrm{Na}_{2} \mathrm{SO}_{4}$ when compared to that of pristine

245 sample (their length of $a$-, $b$-, and c-axes are approximately $\sim 10.4, \sim 10.4$, and $\sim 7.5 \AA$,

246 respectively). On the other hand, a $\sim 0.2 \AA$ contraction along both the $a$-and $b$-axes were

247 observed for the samples leached by $\mathrm{Na}_{2} \mathrm{CO}_{3}$ and $\mathrm{Na}_{3} \mathrm{PO}_{4}$ solutions while the $c$-axis

248 remains the same and is consistent with other samples at $\sim 7.45 \AA$. The observed and

249 calculated diffraction patterns, the residual and the indices of the main reflections of $\mathrm{NaCl}$

250 leached sample are shown in Fig. 5. We identified a secondary phase vanadinite

$251 \mathrm{~Pb}_{5}\left(\mathrm{VO}_{4}\right)_{3} \mathrm{Cl}$, indicating the substitution of iodine by chlorine during $\mathrm{NaCl}$ leaching.

\subsection{Solution composition analysis by ICP-MS and ICP-OES}

The results of the solution analysis on the leachates collected from the leach tests are

254 shown in Fig. 6. The release rates of iodine, lead, and vanadium are depicted as green

255 circles, blue squares, and red triangles, respectively. In Fig. 6(a), iodine release in $\mathrm{NaCl}$

256 solution gradually increased over time, reaching a maximum rate near $0.8 \mathrm{mmol} / \mathrm{m}^{2} / \mathrm{d}$ at

257 day 11 , and then slightly decreased near the end of the 14-day test. The $\mathrm{Pb}$ and V release

258 exhibited similar patterns with a relatively high initial rate around $0.075 \mathrm{mmol} / \mathrm{m}^{2} / \mathrm{d}$, then

259 gradually decreased, and eventually approached a plateau near $0.05 \mathrm{mmol} / \mathrm{m}^{2} / \mathrm{d}$. In Fig.

260 6(b), the release patterns of iodine and vanadium in $\mathrm{Na}_{2} \mathrm{CO}_{3}$ are similar: release rates

261 rapidly reached maximum near day 2 and then gradually decreased over time approaching

262 a plateau. However, the long-term rate of $\mathrm{Pb}$ in $\mathrm{Na}_{2} \mathrm{CO}_{3}$ appears to be constant. In Fig.

263 6(c), the iodine release in $\mathrm{Na}_{2} \mathrm{SO}_{4}$ exhibited a high initial rate approximately 0.32

$264 \mathrm{mmol} / \mathrm{m}^{2} / \mathrm{d}$ and then its rate gradually decreased, eventually approaching a plateau around

$2650.15 \mathrm{mmol} / \mathrm{m}^{2} / \mathrm{d}$. Despite no high initial release, the $\mathrm{Pb}$ and $\mathrm{V}$ release patterns follow the 
266 trend of iodine release: gradually decreased over time and then rebounded near day 10.

267 The Fig. 6(d) describes the element release of iodoapatite in $\mathrm{Na}_{3} \mathrm{PO}_{4}$, which shows

268 constant rates of $\sim 4.5, \sim 3.5$, and $\sim 13 \mathrm{mmol} / \mathrm{m}^{2} / \mathrm{d}$ for the release for iodine, $\mathrm{Pb}$, and $\mathrm{V}$,

269 respectively. Due to the instrumentation limitation and sample consumption, only four

270 leachates from the $\mathrm{Na}_{3} \mathrm{PO}_{4}$ experiment was analyzed for their $\mathrm{Pb}$ content.

271 Leaching rates of $\mathrm{I}, \mathrm{Pb}$, and $\mathrm{V}$ based on the solutions analysis are compared in Figs.

$2727(\mathrm{a}-\mathrm{c})$, respectively. In general, leaching tests conducted in the ionic solutions present

273 significantly higher element release rates than those of deionized water in the order of

$274 \mathrm{Na}_{3} \mathrm{PO}_{4}>\mathrm{Na}_{2} \mathrm{CO}_{3}>\mathrm{Na}_{2} \mathrm{SO}_{4}>$ water, except in the $\mathrm{NaCl}$ solution. In Fig. 7(a), iodine

275 release from $\mathrm{Na}_{3} \mathrm{PO}_{4}, \mathrm{Na}_{2} \mathrm{CO}_{3}$, and $\mathrm{Na}_{2} \mathrm{SO}_{4}$ solutions exhibited a long-term leach pattern

276 similar to that of water leaching: started with a high initial release, then gradually

277 decreased, and eventually stabilized and reached a plateau. The iodine release in $\mathrm{NaCl}$

278 solution, however, presents a different pattern: iodine rate increased from the beginning

279 of leach test to day 11 , when the rate reached maximum and then stabilized. The release

280 rates of $\mathrm{Pb}$ and $\mathrm{V}$ from $\mathrm{NaCl}$ test are relatively constant but not higher than those of water

281 leached as shown in Figs. 7(b, c).

282 The molar ratios in leachate solutions are illustrated in Figs. 7(d, e). Except for the 283 anomalous $\mathrm{NaCl}$ data, the long-term $\mathrm{I} / \mathrm{V}$ ratios in Fig. 7(d) fluctuate around the ratio of 284 water-leached sample within the range of $[0.34,1.02]$, which are higher than the 285 stoichiometric value 0.28 . In Fig. 7(e), the long-term $\mathrm{Pb} / \mathrm{V}$ ratios of $\mathrm{NaCl}$ and $\mathrm{Na}_{2} \mathrm{SO}_{4}$ 286 tests are 1.36 and 1.65, approximate to the stoichiometric value 1.64 , whereas the long287 term ratios from $\mathrm{Na}_{2} \mathrm{CO}_{3}$ and $\mathrm{Na}_{3} \mathrm{PO}_{4}$ tests are 0.95 and 0.27 , significantly lower than 2881.64. 
The phases of interest in this study are the aqueous solutions and the solid surfaces.

The leachate solution chemistry in Fig. 7 shows that iodine release from the sample leached by the $\mathrm{NaCl}$ solution has a distinctive pattern. For the other leach tests, the longterm iodine rates (plateau region in Figs. 6-7) are at least one magnitude higher than that from water leaching. And the order of iodine leach rate, based on solution analysis in Fig 7 (a), is consistent with the orders of $\mathrm{Pb}$ and $\mathrm{V}$ rates in Fig. $7(\mathrm{~b}, \mathrm{c}): R_{\mathrm{Pb} / \mathrm{V} / \mathrm{I}}\left(\mathrm{Na}_{3} \mathrm{PO}_{4}\right)>$ $296 R_{\mathrm{Pb} / \mathrm{V} / \mathrm{I}}\left(\mathrm{Na}_{2} \mathrm{CO}_{3}\right)>R_{\mathrm{Pb} / \mathrm{V} / \mathrm{I}}\left(\mathrm{Na}_{2} \mathrm{SO}_{4}\right)>R_{\mathrm{Pb} / \mathrm{V} / \mathrm{I}}$ (deionized water). In the following section, 297 we will analyze the anomalous result of $\mathrm{NaCl}$ leach test and then explain how element 298 release behaviors differentiate due to the different solution chemistry, such as $\mathrm{pH}$ and 299 ionic species.

\section{Discussion}

\subsection{Anomaly of the sample leached by NaCl solution}

Iodoapatite sample leached by $0.1 \mathrm{~mol} / \mathrm{L} \mathrm{NaCl}$ solution exhibited unique surface phase composition and iodine release pattern. The XRD data in Figs. 4 and 5 show

304 leached surface has no apparent splitting in the region from $25^{\circ}$ to $28^{\circ}(2 \theta)$ and a new

305 peak $(1 \overline{3} 1)$, attributed by a vanadinite phase. This anomaly suggests a reduced structural 306 distortion, which can be contributed by substituting iodide with smaller chloride. The refinement in Fig. 5 confirmed new phase vanadinite was formed on the surface, which

308 resembles the XRD pattern of iodoapatite $\mathrm{Pb}_{9.85}\left(\mathrm{VO}_{4}\right)_{6} \mathrm{I}_{1.7}$. The XRD data is consistent 309 with the EDS result and solution analysis. The Pb EDS band at $2.6 \mathrm{keV}$, in Fig 2, is 310 comparatively enhanced due to the overlap by chlorine signal at $2.6 \mathrm{keV}$. The release 
311 rates of iodine from the $\mathrm{NaCl}$ test in Fig. 6(a) suggest the new phase was growing until

312 the equilibrium state was reached. A similar iodine release pattern was observed in a $\mathrm{pH} 4$

313 semi-dynamic leaching experiment, of which the rate anomaly was caused by the

314 formation of a secondary phase. ${ }^{37}$ The molar ratios of $\mathrm{Pb} / \mathrm{V}$ in Fig. 7(e) approximate to

315 the stoichiometric value 1.6, indicating a congruent dissolution of $\mathrm{Pb}$ and $\mathrm{V}$. The variation

316 of I/V molar ratios in Fig. 7(d) is consistent with that of iodine rates in Fig. 6(a). Both the

$317 \mathrm{I} / \mathrm{V}$ ratios and iodine rates suggest an incongruent release for iodine, unlike the congruent

$318 \mathrm{~Pb}$ and $\mathrm{V}$. The SEM images in Figs. 1(b, e) show that both surfaces leached by $\mathrm{NaCl}$ and

319 deionized water share similar morphology. The new phase vanadinite $\mathrm{Pb}_{5}\left(\mathrm{VO}_{4}\right)_{3} \mathrm{Cl}$,

320 confirmed by the XRD refinement, suggests ion-exchange process between iodide and

321 chloride. This postulation is supported by the solution and surface analysis that 1) a

322 significant amount of iodine was released into $\mathrm{NaCl}$ solution while the $\mathrm{Pb}$ and $\mathrm{V}$ rates are 323 comparable to the data of water leach test as shown in Figs. 6-7;2) the surface alteration 324 revealed by SEM in Fig. 1 and the surface chemistry by EDS in Fig. 2 resemble those of 325 deionized water. Interestingly, the structural deformation of the original iodine-bearing 326 apatite $\mathrm{Pb}_{9.85}\left(\mathrm{VO}_{4}\right)_{6} \mathrm{I}_{1.7}$ appeared to be restored in the chlorine-substituted structure 327 vanadinite $\mathrm{Pb}_{5}\left(\mathrm{VO}_{4}\right)_{3} \mathrm{Cl}$. Given that the ionic radius of chloride $\left(\mathrm{Cl}^{-}, 1.68 \pm 0.19 \AA\right)$ is 328 considerably smaller than that of iodide $\left(\mathrm{I}^{-}, 2.11 \pm 0.19 \AA\right),{ }^{46}$ exchanging the iodide with 329 smaller chloride seems to have repaired the structural deformation.

\subsection{Effect of $\mathrm{pH}$ on iodine release and secondary phase formation}

The solution $\mathrm{pH}$ has a strong effect on the iodine release of the iodoapatite. Chemical 332 properties of the leaching solutions calculated by VMINTEQ are listed in Table 2.

333 According to our previous studies, iodoapatite dissolution in deionized water can be 
334 represented by the congruent release of $\mathrm{Pb}$ and $\mathrm{V} .{ }^{29} \mathrm{In} \mathrm{Fig} .7(\mathrm{~b}, \mathrm{c})$, the $\mathrm{Pb}$ and $\mathrm{V}$ rates

335 from different solutions are generally constant, indicating a constant-dissolution

336 controlled process. The overall dissolution rates from low to high appears to be: $R$

337 (deionized water) $<R\left(\mathrm{Na}_{2} \mathrm{SO}_{4}\right)<R\left(\mathrm{Na}_{2} \mathrm{CO}_{3}\right)<R\left(\mathrm{Na}_{3} \mathrm{PO}_{4}\right)$, which corresponds to the

338 solution $\mathrm{pH}$ values $\sim 6.1, \sim 6.2, \sim 10.3$, and $\sim 10.9$ under $90^{\circ} \mathrm{C}$ as listed in Table 2 .

339 Therefore, increasing $\mathrm{pH}$ from neutral to basic can increase the iodine release by

340 enhancing the overall dissolution of the iodoapatite, which is consistent with previous

341 experimental results on synthetic iodoapatite and natural apatites ${ }^{33,47}$. However, due to the

342 secondary phase formed in $\mathrm{Na}_{2} \mathrm{CO}_{3}$ solutions, the dissolution process was being

343 continuously hindered by the accumulating precipitates. Interestingly, the trend of iodine

344 released in $\mathrm{Na}_{2} \mathrm{CO}_{3}$ solution of $\mathrm{pH} 10.3$ resembles that of leaching iodoapatite under $\mathrm{pH}$

$3454 .{ }^{37}$ Despite the rate difference, both surfaces leached by $\mathrm{pH} 4$ and $\mathrm{pH} 10.3$ formed

346 secondary phases (chervetite and hydroxylvanadinite, respectively). Our previous study

347 showed that the equivalent long-term rate of iodine release under $\mathrm{pH} 6$ is $8.1 \mathrm{mmol} / \mathrm{m}^{2} / \mathrm{d}$,

348 over two magnitudes higher than that of the deionized water $0.036 \mathrm{mmol} / \mathrm{m}^{2} / \mathrm{d}^{37}$

349 Nevertheless, the release rates of iodine leached by the solutions of non-neutral $\mathrm{pH}$ are at

350 least one magnitude higher than that of the neutral $\mathrm{pH}$ solutions due to the enhanced

351 dissolution process.

352 Surface characterizations indicate the presence of new phases under the basic

353 conditions. The XRD analysis in Fig. 4 and Table 1 shows the surfaces leached by the

$354 \mathrm{Na}_{2} \mathrm{CO}_{3}$ and $\mathrm{Na}_{3} \mathrm{PO}_{4}$ solutions were dominated by secondary phases resembling

355 hydroxylvanadinite $\mathrm{Pb}_{10}\left(\mathrm{VO}_{4}\right)_{6}(\mathrm{OH})_{2}$. The SEM in Fig. 1 reveals different grain shapes

356 and sizes from the water leached, while the EDS in Fig. 2 demonstrates that iodine was 
357 depleted on the surface. The solution analysis also supports the formation of new phase

358 given the similar element release pattern to that of $\mathrm{pH} 4$ and incongruent $\mathrm{Pb} / \mathrm{V}$ ratios far

359 away from the stoichiometric value. As shown in Fig. 7, the leaching rates of all elements

360 are at least one magnitude higher than the water leach rates of corresponding elements.

361 The results from this study and those from relevant literature suggest that the solution $\mathrm{pH}$

362 exerts significant effects on the dissolution rate and the secondary phase formation in

363 aqueous environments such as chervetite and hydroxyvanadinite precipitated under acidic

364 and basic conditions, respectively. ${ }^{37,48,49}$

\subsection{Effect of ionic species on the dissolution rate}

In this study, dissolved species affected the sample dissolution process by increasing

367 the ionic strength in solution, which consequently reduced the activity coefficient of

368 dissolved species. As a result, saturation state and solution feedback were reduced, which

369 in return increased the dissolution rate. ${ }^{47}$ Although the $0.1 \mathrm{~mol} / \mathrm{L} \mathrm{Na}_{2} \mathrm{SO}_{4}$ and $0.1 \mathrm{~mol} / \mathrm{L}$

$370 \mathrm{NaCl}$ solutions have approximately the same solution $\mathrm{pH}$ as deionized water, the

371 dissolution rates in these ionic solutions are significantly higher than that of the deionized

372 water. As shown in Table 2, $0.1 \mathrm{~mol} / \mathrm{L} \mathrm{Na}_{2} \mathrm{SO}_{4}$ solution gives total ionic strength of 0.26

$373 \mathrm{~mol} / \mathrm{L}, 0.1 \mathrm{~mol} / \mathrm{L} \mathrm{NaCl}$ solution $0.098 \mathrm{~mol} / \mathrm{L}$, and deionized water $2.04 \times 10^{-6} \mathrm{~mol} / \mathrm{L}$ close

374 to zero. The vast difference in ionic strength leads to different degrees of saturation state.

375 The activity coefficient of the major ions $\mathrm{Na}^{+}, \mathrm{Cl}^{-}$, and $\mathrm{SO}_{4}{ }^{2-}$ in these ionic solutions are

376 ranging from 0.25 to 0.76 , considerably lower than the major ions $\mathrm{H}^{+}$and $\mathrm{OH}^{-}$with a

377 respective activity coefficient 1.00 in the deionized water. The dissolution rate in 0.1

$378 \mathrm{~mol} / \mathrm{L} \mathrm{Na}_{2} \mathrm{SO}_{4}$ solution is higher than the rate in the $0.1 \mathrm{~mol} / \mathrm{L} \mathrm{NaCl}$ solution and

379 deionized water under the same $\mathrm{pH}$ and reaction mechanism, as shown in Fig. 7. 
Moreover, the average release rate of iodine in $\mathrm{Na}_{3} \mathrm{PO}_{4}(\mathrm{pH}$ 10.9) is about one magnitude higher that of $\mathrm{Na}_{2} \mathrm{CO}_{3}(\mathrm{pH}$ 10.3) despite their similar $\mathrm{pHs}$. The difference in rates can be inferred from the difference in ionic strength: $0.29 \mathrm{~mol} / \mathrm{L}$ for $0.1 \mathrm{~mol} / \mathrm{L} \mathrm{Na}_{3} \mathrm{PO}_{4}$ and 0.25 $\mathrm{mol} / \mathrm{L}$ for $\mathrm{Na}_{2} \mathrm{CO}_{3}$ solution.

In addition, no substantial structure change happened to the sample leached by 0.1 $\mathrm{mol} / \mathrm{L} \mathrm{Na}_{2} \mathrm{SO}_{4}$ solution. It is unlikely that anion $\mathrm{SO}_{4}{ }^{2-}$ can be incorporated into apatite structure as there is no evidence from surface characterization and solution analysis to support that. No structural change was detected by the XRD characterization. The SEM images and EDS analysis in Figs. 1 and 2 show that the $\mathrm{Na}_{2} \mathrm{SO}_{4}$ and water leached surfaces have a similar grain size, surface morphology, and chemical composition. The element release rates and ratios in Fig. 7 and 8 demonstrate a similar leach behavior between samples leached by $\mathrm{Na}_{2} \mathrm{SO}_{4}$ and deionized water. The similarities in surface alteration and leaching behavior between samples leached by $\mathrm{Na}_{2} \mathrm{SO}_{4}$ and water suggest that the iodine release in $\mathrm{Na}_{2} \mathrm{SO}_{4}$ solution was controlled by short-term diffusion and long-term dissolution and the release of $\mathrm{Pb}$ and $\mathrm{V}$ is controlled by congruent dissolution. No precipitated was observed on $\mathrm{Na}_{2} \mathrm{SO}_{4}$ leached surface, which is also similar to the surface leached by water.

In terms of the surface precipitation, the SEM images in Figs. 1 (c, f) reflect intense surface alterations in the solutions of $\mathrm{Na}_{3} \mathrm{PO}_{4}$ and $\mathrm{Na}_{2} \mathrm{CO}_{3}$. The leached surfaces yielded XRD patterns similar to the standard hydroxyvanadinite $\mathrm{Pb}_{5}\left(\mathrm{VO}_{4}\right)_{3} \mathrm{OH}$. However, significant contractions of $a$-and $b$-axes as shown in Table 2 indicate the size of $\mathrm{VO}_{4}$ site was reduced, which could be caused by a substitution of smaller groups. ${ }^{50}$ The IR spectroscopy of the sample leached by $\mathrm{Na}_{3} \mathrm{PO}_{4}$ confirms the existence of $\mathrm{P}-\mathrm{O}$ bond and 
$\mathrm{OH}^{-}$. Furthermore, the EDS detected phosphorus signal, which also supports that $\mathrm{PO}_{4}$ group was in $\mathrm{VO}_{4}$ site. The molar ratios of $\mathrm{Pb} / \mathrm{V}$ in Fig. 7 show a deficiency of $\mathrm{Pb}$ relative to $\mathrm{V}$ in $\mathrm{Na}_{3} \mathrm{PO}_{4}$ leaching test. These evidences suggest the precipitates are a product of 406 hydroxyvanadinite with mixed site: $\mathrm{Pb}_{10}\left(\mathrm{VO}_{4}\right)_{\mathrm{n}}\left(\mathrm{PO}_{4}\right)_{6-\mathrm{n}}(\mathrm{OH})_{2}$. The site mixing is possible 407 since $\mathrm{Pb}_{10}\left(\mathrm{VO}_{4}\right)_{\mathrm{x}}\left(\mathrm{PO}_{4}\right)_{6-\mathrm{x}}(\mathrm{OH})_{2}$ can occur during wet chemistry reactions under similar 408 conditions. ${ }^{48}$ Carbonate is known to be incorporated into apatite structure by 409 substitution. ${ }^{50-53}$ Given that phosphate $\left(\mathrm{PO}_{4}{ }^{3-} \text {, ionic radius } 2.30 \pm 0.42 \AA\right)^{46}$ can replace

410 vanadate in iodoapatite, ${ }^{48}$ it is reasonable to presume that carbonate of a smaller ionic 411 radius $\left(\mathrm{CO}_{3}{ }^{2-}, 1.89 \pm 0.19 \AA\right)^{46}$ can substitute vanadate in a similar crystal structure.

412 Therefore, the secondary phase formed on in the $\mathrm{Na}_{2} \mathrm{CO}_{3}$ solution is $\mathrm{Pb}_{10}\left(\mathrm{VO}_{4}\right)_{6-}$ $413 \mathrm{~m}\left(\mathrm{CO}_{3}\right)_{1.5 \mathrm{~m}}(\mathrm{OH})_{2}$. environments contributing to the iodine release. Our previous study on iodine release in deionized water suggests that the iodine release is driven by short-term diffusion and long-term 419 dissolution. ${ }^{29}$ Diffusion and dissolution are affected by various factors of the solution 420 chemistry, such as solution ionic strength, $\mathrm{pH}$, and secondary phase formation resulted 421 from a supersaturation of the solution with respect to low solubility species. In neutral pH 422 solutions, the iodine release is subjected to the substitution of iodine by anionic species in 423 solution such as $\mathrm{OH}^{-}$and $\mathrm{Cl}^{-}$. When dealing with solutions of comparable $\mathrm{pH}$, a higher 424 ionic strength, due to the ionic content, can enhance the dissolution by changing 425 saturation conditions. Solution $\mathrm{pH}$ other than near neutral can increase the dissolution by 
426 exponentially accelerating the dissolution process. The resulting rapid dissolution can

427 often lead to the precipitation of secondary phases when the solution approaches the

428 supersaturation state of low solubility phases. Possible secondary phases include

429 chervetite $\mathrm{Pb}_{2} \mathrm{~V}_{2} \mathrm{O}_{7}$ under acidic condition ${ }^{37}$ and hydroxylvanadinite $\mathrm{Pb}_{5}\left(\mathrm{VO}_{4}\right)_{3} \mathrm{OH}$ under

430 basic condition.

\section{Conclusions}

432

433

434

435

436

437

438

439

440

441

442 investigation on the impact of solution chemistry reveals new complexities of the

443 dissolution kinetics of crystalline waste form during environmental degradation, Unlike

444 fresh water with low ion content, high concentrations of aqueous species commonly

445 found in underground brines can compromise the chemical durability of crystalline waste

446 form in a geological repository. For this specific waste form, maintaining neutral $\mathrm{pH}$ and

447 low ion content in aqueous solutions is important to the disposal safety of radioactive

448 iodine. Since iodine is one of the most challenging radionuclides to immobilize, building 
449 a comprehensive theoretical framework of iodine immobilization can significantly

450 advance the research in nuclear waste disposal safety.

\section{Conflicts of interest}

452 There are no conflicts to declare.

\section{Acknowledgements}

454 This work was supported as part of the Center for Performance and Design of Nuclear

455 Waste Forms and Containers, an Energy Frontier Research Center funded by the U.S.

456 Department of Energy, Office of Science, Basic Energy Sciences (DE-SC0016584). The

457 sample surface characterizations were carried out at the Shared Instrumentation Facilities

458 (SIF) and Center for Advanced Microstructures and Devices (CAMD) of Louisiana State

459 University. We thank our XRD \& Geochemistry Lab Researcher Wanda LeBlanc for

460 operating XRD experiments at SIF and facilitating our experiments in Geochemistry Lab.

461 We also thank Dr. Orhan Kizilkaya from CAMD for his assistance on infrared

462 spectroscopy.

\section{Date Availability}

464 Data will be made available on request 


\section{References}

466 (1) Climate Change 2014: Mitigation of Climate Change: Working Group III Contribution to the Fifth Assessment Report of the Intergovernmental Panel on Climate Change; Intergovernmental Panel

(2) Alley, W. M.; Alley, R. The Growing Problem of Stranded Used Nuclear Fuel. Environ. Sci. Technol. 2014, 48 (4), 2091-2096. https://doi.org/10.1021/es405114h.

(3) Nichols, A. L.; Verpelli, M.; Aldama, D. L. Handbook of Nuclear Data for Safeguards; INDC(NDS)-0502; International Atomic Energy Agency, 2007.

(4) Ojovan, M. I.; Lee, W. E. 10 - Long-Lived Waste Radionuclides. In An Introduction to Nuclear Waste Immobilisation (Second Edition); Ojovan, M. I., Lee, W. E., Eds.; Elsevier: Oxford, 2014; pp 107-115. https://doi.org/10.1016/B978-0-08-099392-8.00010-3.

(5) Aimoz, L.; Wieland, E.; Taviot-Guého, C.; Dähn, R.; Vespa, M.; Churakov, S. V. Structural Insight into lodide Uptake by AFm Phases. Environ. Sci. Technol. 2012, 46 (7), 3874-3881. https://doi.org/10.1021/es204470e.

(6) Um, W.; Serne, R. J.; Krupka, K. M. Linearity and Reversibility of lodide Adsorption on Sediments from Hanford, Washington under Water Saturated Conditions. Water Res. 2004, 38 (8), 20092016. https://doi.org/10.1016/j.watres.2004.01.026.

(7) Coughtrey, P. J.; Thorne, M. C. Radionuclide Distribution and Transport in Terrestrial and Aquatic Ecosystems. A Critical Review of Data; 1983; Vol. 1.

(8) Whitehead, D. C. The Distribution and Transformations of lodine in the Environment. Environ. Int. 1984, 10 (4), 321-339. https://doi.org/10.1016/0160-4120(84)90139-9.

(9) Schwehr, K. A.; Santschi, P. H.; Kaplan, D. I.; Yeager, C. M.; Brinkmeyer, R. Organo-lodine Formation in Soils and Aquifer Sediments at Ambient Concentrations. Environ. Sci. Technol. 2009, 43 (19), 7258-7264. https://doi.org/10.1021/es900795k.

(10) Shimamoto, Y. S.; Takahashi, Y.; Terada, Y. Formation of Organic lodine Supplied as lodide in a Soil-Water System in Chiba, Japan. Environ. Sci. Technol. 2011, 45 (6), 2086-2092. https://doi.org/10.1021/es1032162.

(11) Fuge, R.; Johnson, C. C. Iodine and Human Health, the Role of Environmental Geochemistry and Diet, a Review. Appl. Geochem. 2015, 63, 282-302. https://doi.org/10.1016/j.apgeochem.2015.09.013.

(12) Patrick, L. lodine: Deficiency and Therapeutic Considerations. Altern. Med. Rev. 2008, 13 (2), 116127.

(13) Audubert, F.; Carpena, J.; Lacout, J. L.; Tetard, F. Elaboration of an lodine-Bearing Apatite lodine Diffusion into a Pb3(VO4)2 Matrix. Solid State Ion. 1997, 95 (1), 113-119. https://doi.org/10.1016/S0167-2738(96)00570-X.

(14) Garino, T. J.; Nenoff, T. M.; Krumhansl, J. L.; Rademacher, D. X. Low-Temperature Sintering Bi-SiZn-Oxide Glasses for Use in Either Glass Composite Materials or Core/Shell 129I Waste Forms. J. Am. Ceram. Soc. 2011, 94 (8), 2412-2419. https://doi.org/10.1111/j.1551-2916.2011.04542.x.

(15) Krumhansl, J. L.; Nenoff, T. M. Hydrotalcite-like Layered Bismuth-lodine-Oxides as Waste Forms. Applied Geochemistry 2011, 26 (1), 57-64. https://doi.org/10.1016/j.apgeochem.2010.11.003.

(16) Sava, D. F.; Garino, T. J.; Nenoff, T. M. lodine Confinement into Metal-Organic Frameworks (MOFs): Low-Temperature Sintering Glasses To Form Novel Glass Composite Material (GCM) Alternative Waste Forms. Ind. Eng. Chem. Res. 2012, 51 (2), 614-620. https://doi.org/10.1021/ie200248g.

(17) Sava, D. F.; Rodriguez, M. A.; Chapman, K. W.; Chupas, P. J.; Greathouse, J. A.; Crozier, P. S.; Nenoff, T. M. Capture of Volatile lodine, a Gaseous Fission Product, by Zeolitic Imidazolate 
550

551

552

553

554

555

556

Framework-8. J. Am. Chem. Soc. 2011, 133 (32), 12398-12401. https://doi.org/10.1021/ja204757x.

(18) Riley, B. J.; Vienna, J. D.; Strachan, D. M.; McCloy, J. S.; Jerden, J. L. Materials and Processes for the Effective Capture and Immobilization of Radioiodine: A Review. J. Nucl. Mater. 2016, 470, 307-326. https://doi.org/10.1016/j.jnucmat.2015.11.038.

(19) Frankel, G. S.; Vienna, J. D.; Lian, J.; Scully, J. R.; Gin, S.; Ryan, J. V.; Wang, J.; Kim, S. H.; Windl, W.; Du, J. A Comparative Review of the Aqueous Corrosion of Glasses, Crystalline Ceramics, and Metals. npj Materials Degradation 2018, 2 (1), 15. https://doi.org/10.1038/s41529-018-0037-2.

(20) Faucon, P.; Adenot, F.; Jacquinot, J. F.; Petit, J. C.; Cabrillac, R.; Jorda, M. Long-Term Behaviour of Cement Pastes Used for Nuclear Waste Disposal: Review of Physico-Chemical Mechanisms of Water Degradation. Cem. Concr. Res. 1998, 28 (6), 847-857. https://doi.org/10.1016/S00088846(98)00053-2.

(21) Frankel, G. S.; Vienna, J.; Lian, J. WastePD, an Innovative Center on Materials Degradation. npj Mater. Degrad. 2017, 1 (1), 5. https://doi.org/10.1038/s41529-017-0002-5.

(22) Chapman, N. A.; McKinley, I. G.; Smellie, J. a. T. The Potential of Natural Analogues in Assessing Systems for Deep Disposal of High-Level Radioactive Waste; EIR--545; Eidgenoessisches Inst. fuer Reaktorforschung: Sweden, 1984.

(23) Kato, H.; Kato, O.; Tanabe, H. Review of Immobilization Techniques of Radioactive lodine for Geological Disposal. 2002. https://doi.org/10.11484/JAERI-Conf-2002-004.

(24) Chapman, K. W.; Chupas, P. J.; Nenoff, T. M. Radioactive lodine Capture in Silver-Containing Mordenites through Nanoscale Silver lodide Formation. J. Am. Chem. Soc. 2010, 132 (26), 88978899. https://doi.org/10.1021/ja103110y.

(25) Yao, T.; Lu, F.; Sun, H.; Wang, J.; Ewing, R. C.; Lian, J. Bulk lodoapatite Ceramic Densified by Spark Plasma Sintering with Exceptional Thermal Stability. J. Am. Ceram. Soc. 2014, 97 (8), 2409-2412. https://doi.org/10.1111/jace.13101.

(26) Maddrell, E.; Gandy, A.; Stennett, M. The Durability of lodide Sodalite. Journal of Nuclear Materials 2014, 449 (1), 168-172. https://doi.org/10.1016/j.jnucmat.2014.03.016.

(27) Chong, S.; Peterson, J. A.; Riley, B. J.; Tabada, D.; Wall, D.; Corkhill, C. L.; McCloy, J. S. GlassBonded lodosodalite Waste Form for Immobilization of 129I. J. Nucl. Mater. 2018, 504, 109-121. https://doi.org/10.1016/j.jnucmat.2018.03.033.

(28) Le Gallet, S.; Campayo, L.; Courtois, E.; Hoffmann, S.; Grin, Yu.; Bernard, F.; Bart, F. Spark Plasma Sintering of lodine-Bearing Apatite. J. Nucl. Mater. 2010, 400 (3), 251-256. https://doi.org/10.1016/j.jnucmat.2010.03.011.

(29) Zhang, Z.; Heath, A.; T. Valsaraj, K.; L. Ebert, W.; Yao, T.; Lian, J.; Wang, J. Mechanism of lodine Release from lodoapatite in Aqueous Solution. RSC Adv. 2018, 8 (8), 3951-3957. https://doi.org/10.1039/C7RA11049A.

(30) Gauthier-Lafaye, F. 2 Billion Year Old Natural Analogs for Nuclear Waste Disposal: The Natural Nuclear Fission Reactors in Gabon (Africa). C. R. Phys. 2002, 3 (7), 839-849. https://doi.org/10.1016/S1631-0705(02)01351-8.

(31) Uno, M.; Shinohara, M.; Kurosaki, K.; Yamanaka, S. Some Properties of a Lead Vanadolodoapatite Pb10(VO4)6I2. J. Nucl. Mater. 2001, 294 (1), 119-122. https://doi.org/10.1016/S0022-3115(01)00462-7.

(32) National Research Council. Scho; 2011. https://doi.org/10.17226/13100.

(33) Guy, C.; Audubert, F.; Lartigue, J.-E.; Latrille, C.; Advocat, T.; Fillet, C. New Conditionings for Separated Long-Lived Radionuclides. C. R. Phys. 2002, 3 (7), 827-837. https://doi.org/10.1016/S1631-0705(02)01377-4. 
(34) Zhang, M.; Maddrell, E. R.; Abraitis, P. K.; Salje, E. K. H. Impact of Leach on Lead Vanadolodoapatite [Pb5(VO4)3I]: An Infrared and Raman Spectroscopic Study. Mater. Sci. Eng. B 2007, 137 (1), 149-155. https://doi.org/10.1016/j.mseb.2006.11.003.

(35) Coulon, A.; Grandjean, A.; Laurencin, D.; Jollivet, P.; Rossignol, S.; Campayo, L. Durability Testing of an lodate-Substituted Hydroxyapatite Designed for the Conditioning of 129I. J. Nucl. Mater. 2017, 484, 324-331. https://doi.org/10.1016/j.jnucmat.2016.10.047.

(36) ASTM C1220-17, Standard Test Method for Static Leaching of Monolithic Waste Forms for Disposal of Radioactive Waste; ASTM International: West Conshohocken, PA, 2017.

(37) Zhang, Z.; Ebert, W. L.; Yao, T.; Lian, J.; Valsaraj, K. T.; Wang, J. Chemical Durability and Dissolution Kinetics of lodoapatite in Aqueous Solutions. ACS Earth Space Chem. 2019, 3 (3), $452-$ 462. https://doi.org/10.1021/acsearthspacechem.8b00162.

(38) Zhu, Y.; Zhang, X.; Chen, Y.; Xie, Q.; Lan, J.; Qian, M.; He, N. A Comparative Study on the Dissolution and Solubility of Hydroxylapatite and Fluorapatite at $25^{\circ} \mathrm{C}$ and $45^{\circ} \mathrm{C}$. Chem. Geol. 2009, 268 (1), 89-96. https://doi.org/10.1016/j.chemgeo.2009.07.014.

(39) Cazalbou, S.; Eichert, D.; Ranz, X.; Drouet, C.; Combes, C.; Harmand, M. F.; Rey, C. Ion Exchanges in Apatites for Biomedical Application. J. Mater. Sci. Mater. Med. 2005, 16 (5), 405-409. https://doi.org/10.1007/s10856-005-6979-2.

(40) Brenan, J. Kinetics of Fluorine, Chlorine and Hydroxyl Exchange in Fluorapatite. Chem. Geol. 1993, 110 (1), 195-210. https://doi.org/10.1016/0009-2541(93)90254-G.

(41) Dorozhkin, S. V. A Review on the Dissolution Models of Calcium Apatites. Prog. Cryst. Growth Charact. 2002, 44 (1), 45-61. https://doi.org/10.1016/S0960-8974(02)00004-9.

(42) Petř́ček, V.; Dušek, M.; Palatinus, L. Crystallographic Computing System JANA2006: General Features. Z. Kristallogr. Cryst. Mater. 2014, 229 (5), 345-352. https://doi.org/10.1515/zkri-20141737.

(43) Audubert, F.; Savariault, J.-M.; Lacout, J.-L. Pentalead Tris(Vanadate) lodide, a Defect VanadiniteType Compound. Acta Crystallogr. C 1999, 55 (3), 271-273. https://doi.org/10.1107/S0108270198005034.

(44) Ślósarczyk, A.; Paszkiewicz, Z.; Paluszkiewicz, C. FTIR and XRD Evaluation of Carbonated Hydroxyapatite Powders Synthesized by Wet Methods. J. Mol. Struct. 2005, 744-747, 657-661. https://doi.org/10.1016/j.molstruc.2004.11.078.

(45) Merry, J. C.; Gibson, I. R.; Best, S. M.; Bonfield, W. Synthesis and Characterization of Carbonate Hydroxyapatite. J. Mater. Sci. Mater. Med. 1998, 9 (12), 779-783. https://doi.org/10.1023/A:1008975507498.

(46) Roobottom, H. K.; Jenkins, H. D. B.; Passmore, J.; Glasser, L. Thermochemical Radii of Complex Ions. J. Chem. Educ. 1999, 76 (11), 1570. https://doi.org/10.1021/ed076p1570.

(47) Guidry, M. W.; Mackenzie, F. T. Experimental Study of Igneous and Sedimentary Apatite Dissolution: Control of PH, Distance from Equilibrium, and Temperature on Dissolution Rates. Geochim. Cosmochim. Acta 2003, 67 (16), 2949-2963. https://doi.org/10.1016/S00167037(03)00265-5.

(48) Cao, C.; Chong, S.; Thirion, L.; C. Mauro, J.; S. McCloy, J.; Goel, A. Wet Chemical Synthesis of Apatite-Based Waste Forms - A Novel Room Temperature Method for the Immobilization of Radioactive lodine. J. Mater. Chem. C 2017, 5 (27), 14331-14342. https://doi.org/10.1039/C7TA00230K.

(49) Campayo, L.; Audubert, F.; Lartigue, J.-E.; Courtois-Manara, E.; Gallet, S. L.; Bernard, F.; Lemesle, T.; Mear, F. O.; Montagne, L.; Coulon, A.; et al. French Studies on the Development of Potential Conditioning Matrices for lodine 129. Mater. Res. Soc. Symp. Proc. 2015, 1744, 15-20. https://doi.org/10.1557/opl.2015.309. 
604

605

606

607

608

609

610

611

612

613

(50) Zapanta-Legeros, R. Effect of Carbonate on the Lattice Parameters of Apatite. Nature 1965, 206 (4982), 403. https://doi.org/10.1038/206403a0.

(51) White, T. J.; Dong, Z. L. Structural Derivation and Crystal Chemistry of Apatites. Acta Cryst. B 2003, 59 (1), 1-16. https://doi.org/10.1107/S0108768102019894.

(52) Fleet, M. E.; Liu, X. Coupled Substitution of Type A and B Carbonate in Sodium-Bearing Apatite. Biomaterials 2007, 28 (6), 916-926. https://doi.org/10.1016/j.biomaterials.2006.11.003.

(53) Landi, E.; Tampieri, A.; Celotti, G.; Vichi, L.; Sandri, M. Influence of Synthesis and Sintering Parameters on the Characteristics of Carbonate Apatite. Biomaterials 2004, 25 (10), 1763-1770. https://doi.org/10.1016/j.biomaterials.2003.08.026. 


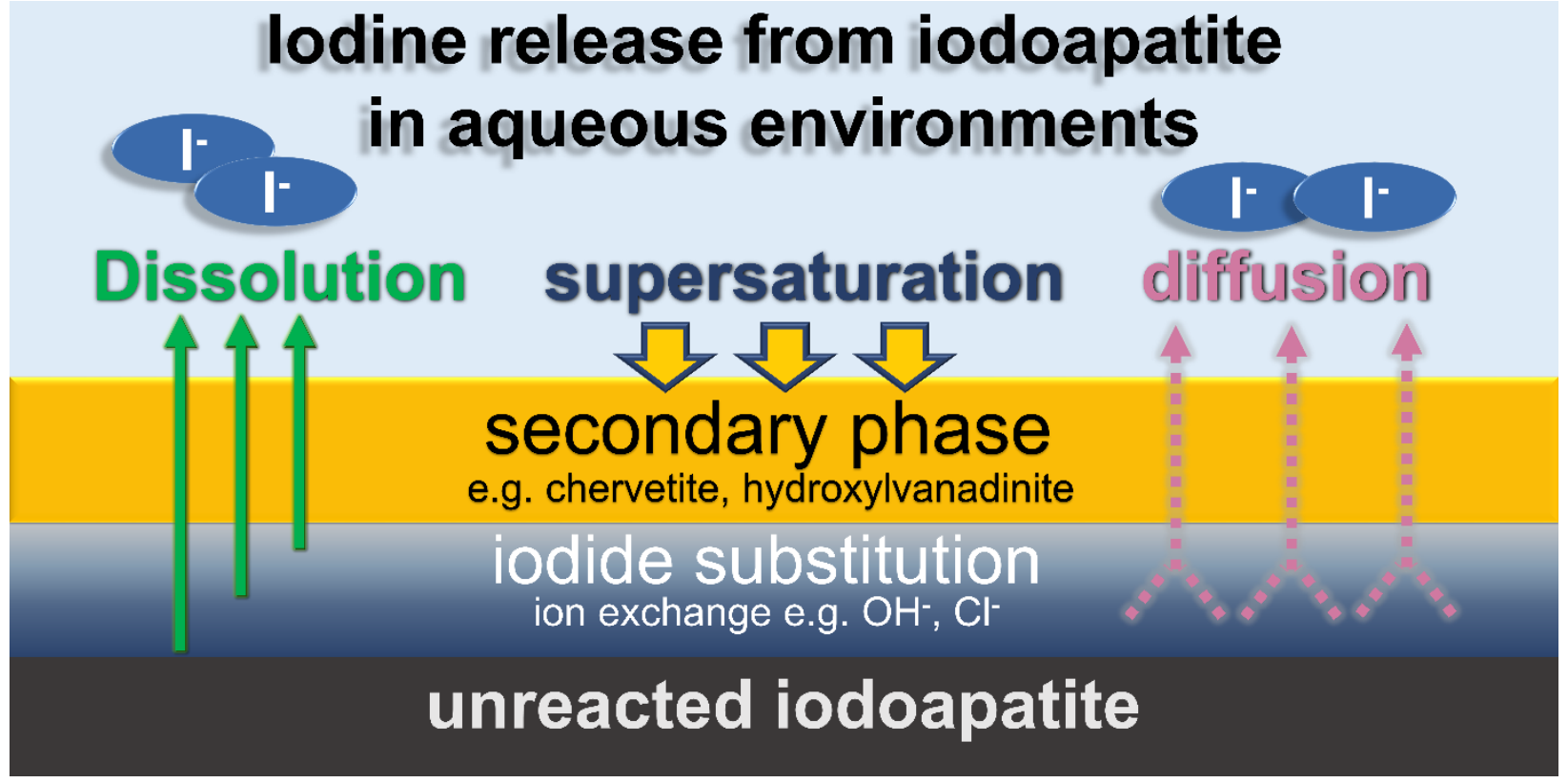



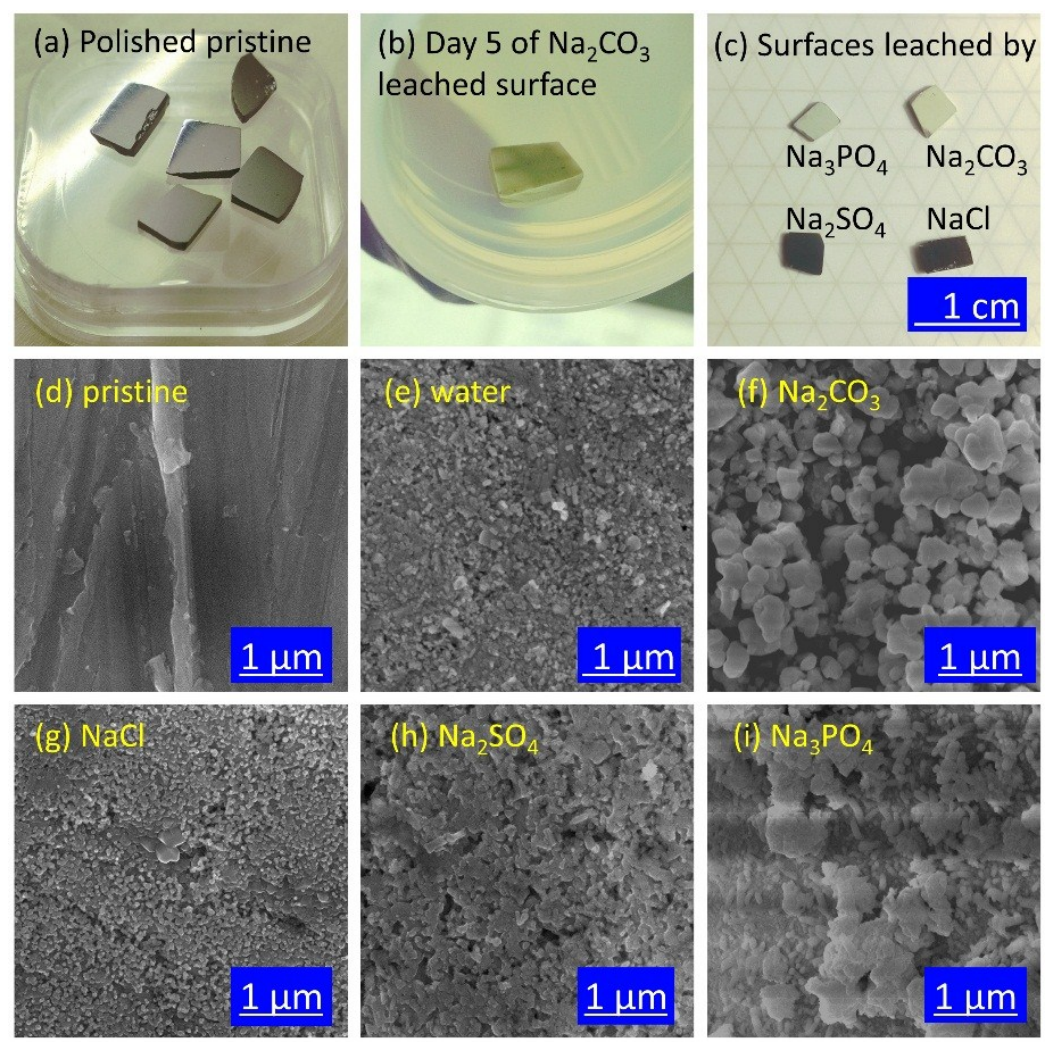

618 Fig. 1.(a) Polished pristine iodoapatite samples before test, (b) iodoapatite leached 619 surface during the $5^{\text {th }}$ replacement of $\mathrm{Na}_{2} \mathrm{CO}_{3}$ solution, (c) surface leached by at the end 620 of 14-day leaching tests, SEM images of (a) a polished pristine iodoapatite and the 621 samples leached by (b) deionized water, (c) $0.1 \mathrm{~mol} / \mathrm{L} \mathrm{Na}_{2} \mathrm{CO}_{3}$, (d) $0.1 \mathrm{~mol} / \mathrm{L} \mathrm{NaCl}$, (e) $6220.1 \mathrm{~mol} / \mathrm{L} \mathrm{Na}_{2} \mathrm{SO}_{4}$, and (f) $0.1 \mathrm{~mol} / \mathrm{L} \mathrm{Na}_{3} \mathrm{PO}_{4}$. 


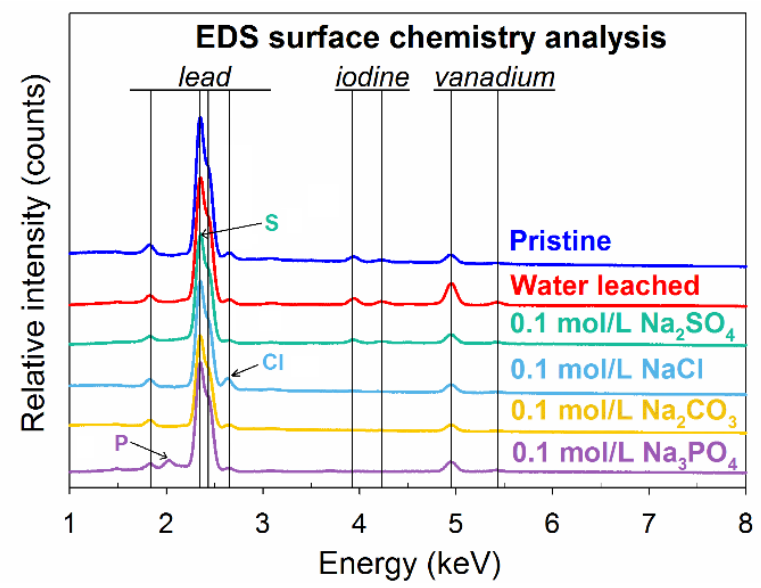

625 Fig. 2. EDS spectra of a pristine iodoapatite and the samples leached by deionized 626 water, $0.1 \mathrm{~mol} / \mathrm{L} \mathrm{NaCl}, 0.1 \mathrm{~mol} / \mathrm{L} \mathrm{Na} \mathrm{CO}_{3}, 0.1 \mathrm{~mol} / \mathrm{L} \mathrm{Na} 3 \mathrm{PO}_{4}$, and $0.1 \mathrm{~mol} / \mathrm{L} \mathrm{Na} \mathrm{SO}_{4}$ 627 solutions. 


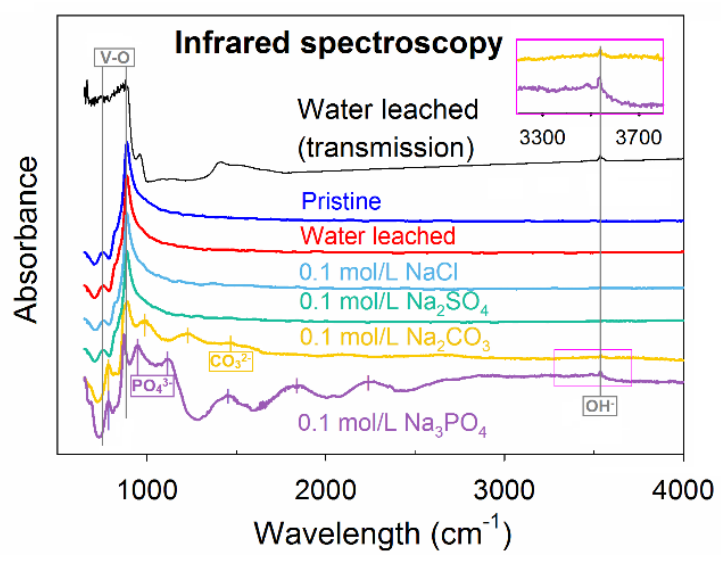

630 Fig. 3. Infrared spectroscopy of pristine iodoapatite and leached samples by deionized 631 water, $\mathrm{NaCl}, \mathrm{Na}_{2} \mathrm{SO}_{4}, \mathrm{Na}_{2} \mathrm{CO}_{3}$, and $\mathrm{Na}_{3} \mathrm{PO}_{4}$ solutions. 


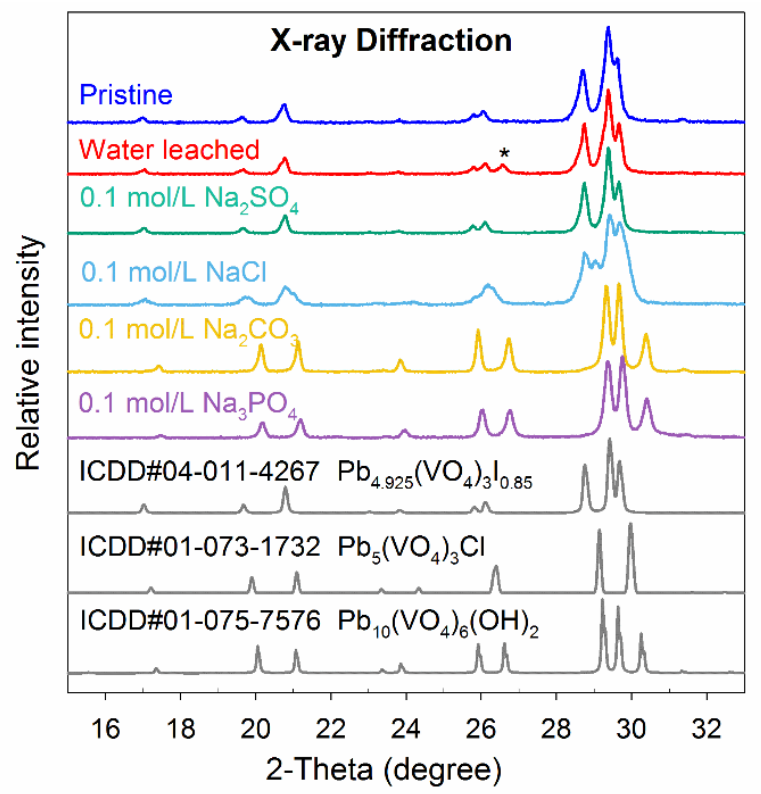

634 Fig. 4. XRD patterns of a pristine iodoapatite and the samples leached by deionized

635 water, $0.1 \mathrm{~mol} / \mathrm{L} \mathrm{Na}_{2} \mathrm{SO}_{4}, 0.1 \mathrm{~mol} / \mathrm{L} \mathrm{NaCl}, 0.1 \mathrm{~mol} / \mathrm{L} \mathrm{Na} 2 \mathrm{CO}_{3}$, and $0.1 \mathrm{~mol} / \mathrm{L} \mathrm{Na} 3 \mathrm{PO}_{4}$. In 636 addition, standard XRD spectra of iodoapatite, vanadinite, and hydroxylvanadinite are 637 listed for comparison. * denotes the graphite impurity introduced during sample 638 synthesis. ${ }^{25}$ 


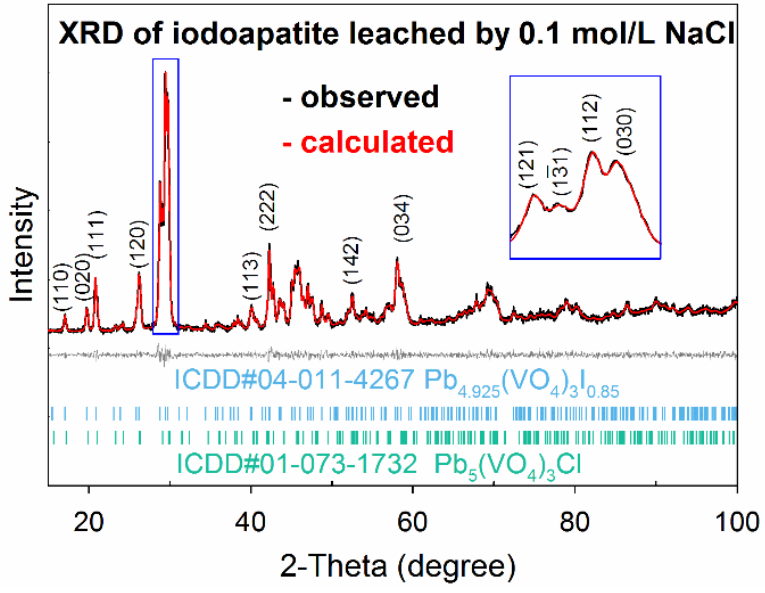

640 Fig. 5. XRD phase analysis of the iodoapatite sample surface leached by 0.1 $641 \mathrm{~mol} / \mathrm{L} \mathrm{NaCl}$ solution. Two phases were identified: iodoapatite and vanadinite. 

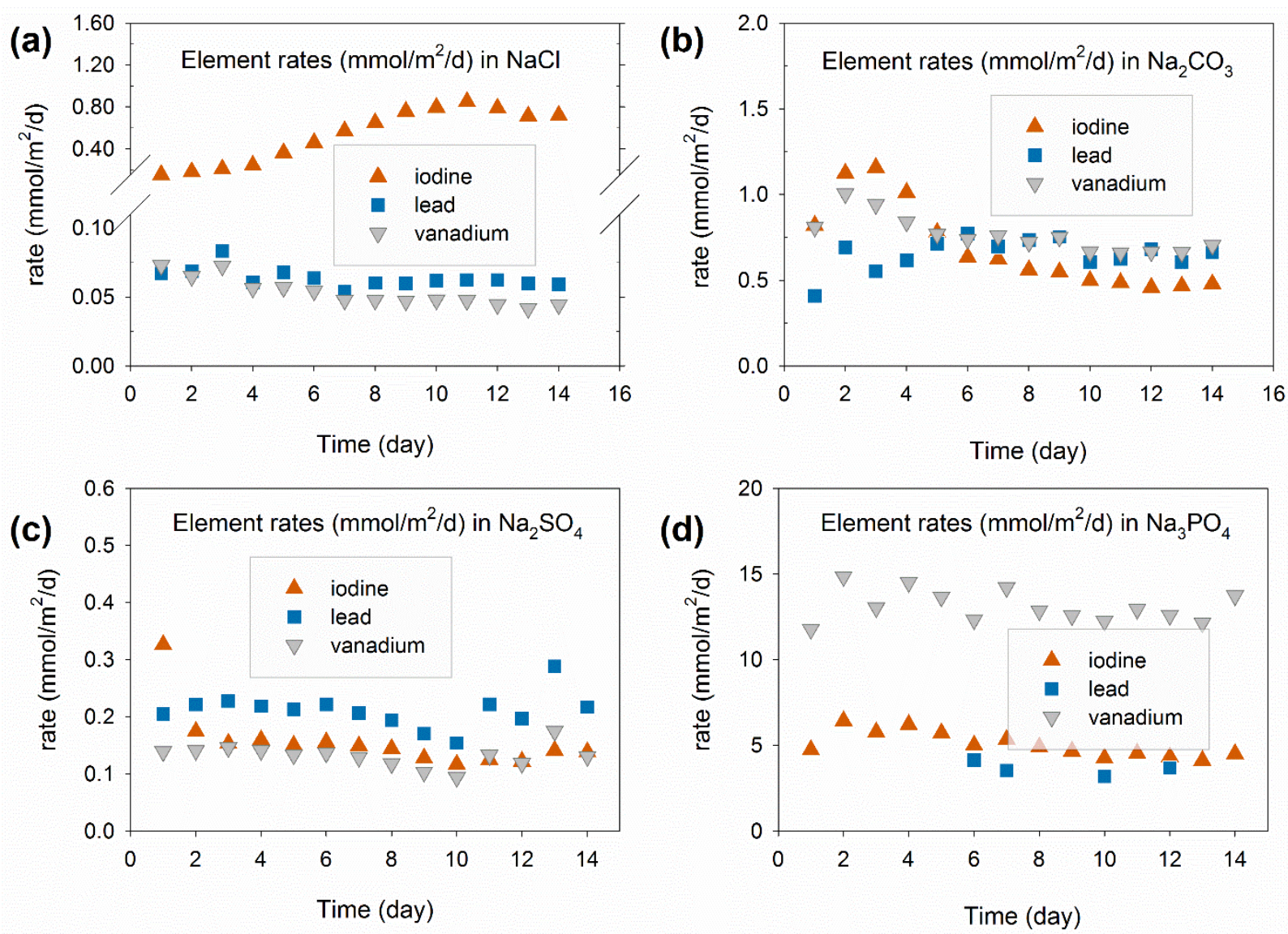

Fig. 6. Solution analysis of collected leachates from 14 days semi-dynamic leach tests 646 on iodoapatite samples in (a) $0.1 \mathrm{~mol} / \mathrm{L} \mathrm{NaCl}$, (b) $0.1 \mathrm{~mol} / \mathrm{L} \mathrm{Na} 2 \mathrm{CO}_{3}$, (c) $0.1 \mathrm{~mol} / \mathrm{L}$ $647 \quad \mathrm{Na}_{2} \mathrm{SO}_{4}$, and (d) $0.1 \mathrm{~mol} / \mathrm{L} \mathrm{Na} \mathrm{NaO}_{4}$. 

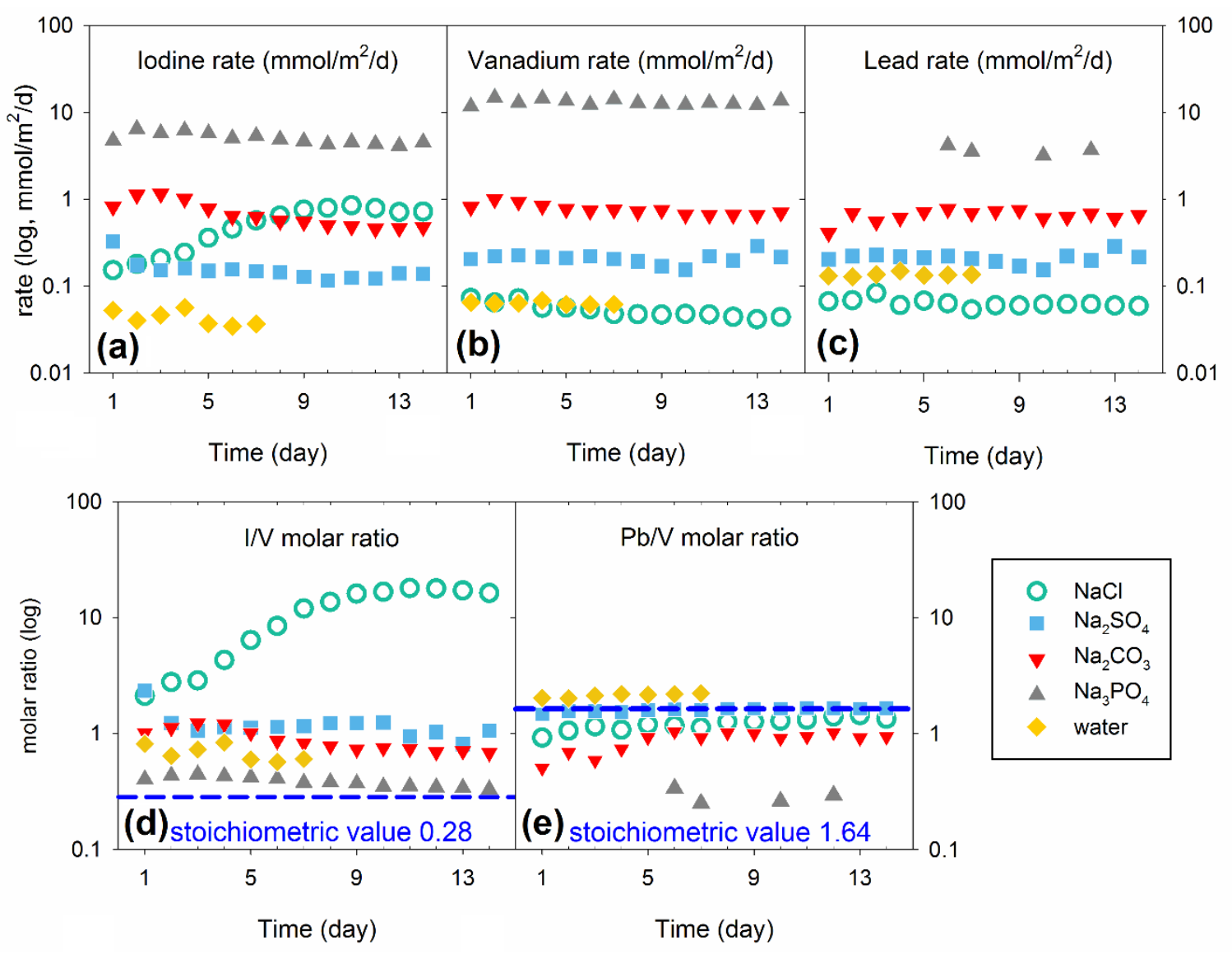

650 Fig. 7. Comparison of element release rate of iodine (a), vanadium (b), and lead (c) in 651 the leachate solutions from different leach tests. Molar ratios of $\mathrm{Pb} / \mathrm{V}$ (d) and I/V (e) in 652 leachate solutions from leach tests in $\mathrm{NaCl}, \mathrm{Na}_{2} \mathrm{SO}_{4}, \mathrm{Na}_{2} \mathrm{CO}_{3}, \mathrm{Na}_{3} \mathrm{PO}_{4}$, and deionized 653 water. 


\section{lodine release from iodoapatite}

in aqueous environments

Dissolution

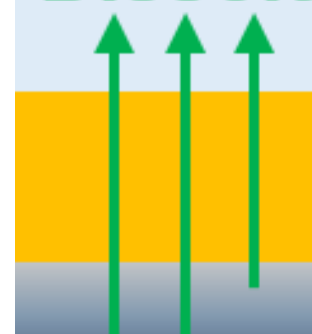

\section{supersaturation}

\section{secondary phase}

e.g. chervetite, hydroxylvanadinite

\section{iodide substitution} ion exchange e.g. $\mathrm{OH}^{-}, \mathrm{Cl}^{-}$

\section{unreacted iodoapatite}

Fig. 8. Schematic diagram illustrates major processes that control the iodine release 657 from iodoapatite in aqueous environments 
658 Table. 1 Crystallographic parameters based on the XRD refinements by Le Bail 659 algorithm.

\begin{tabular}{|c|c|c|c|c|c|}
\hline \multirow{2}{*}{$\begin{array}{l}\text { Leach test } \\
\text { condition }\end{array}$} & \multicolumn{5}{|c|}{ Refined parameters } \\
\hline & $a, b(a=b, \AA)$ & $c(\AA)$ & GoF & $\begin{array}{l}\mathbf{R}_{\mathbf{p}} \\
(\%)\end{array}$ & $\begin{array}{l}R_{w p} \\
(\%)\end{array}$ \\
\hline Pristine & $10.4420(3)$ & $7.4756(3)$ & 1.32 & 5.16 & 6.53 \\
\hline Water & $10.4325(3)$ & $7.4864(3)$ & 1.63 & 6.04 & 7.73 \\
\hline $0.1 \mathrm{~mol} / \mathrm{L} \mathrm{Na}_{2} \mathrm{SO}_{4}$ & $10.4336(2)$ & $7.4837(2)$ & 1.39 & 4.60 & 5.93 \\
\hline $0.1 \mathrm{~mol} / \mathrm{L} \mathrm{Na}_{2} \mathrm{CO}_{3}$ & $10.1923(2)$ & $7.4656(2)$ & 1.65 & 4.85 & 6.44 \\
\hline $0.1 \mathrm{~mol} / \mathrm{L} \mathrm{Na}_{3} \mathrm{PO}_{4}$ & $10.1984(2)$ & $7.4449(2)$ & 1.43 & 4.74 & 6.23 \\
\hline \multirow{3}{*}{$\begin{array}{l}0.1 \mathrm{~mol} / \mathrm{L} \mathrm{NaCl} \\
(2 \text { phases })\end{array}$} & $10.4443(6)$ & $7.4796(5)$ & & & \\
\hline & & & 1.17 & 4.12 & 5.28 \\
\hline & $10.3536(8)$ & $7.3735(8)$ & & & \\
\hline $\begin{array}{c}\mathrm{Pb}_{4.925}\left(\mathrm{VO}_{4}\right)_{3} \mathrm{l}_{0.85} \\
\text { [ICDD\#04-011-4267] }\end{array}$ & 10.422 & 7.467 & \multicolumn{3}{|c|}{$\begin{array}{c}\text { Crystal system: } \\
\text { hexagonal }\end{array}$} \\
\hline \multirow[t]{2}{*}{$\begin{array}{c}\mathrm{Pb}_{5}\left(\mathrm{VO}_{4}\right)_{3}(\mathrm{OH}) \\
{[\mathrm{ICDD} \# 01-075-7576]}\end{array}$} & 10.2242 & 7.4537 & \multicolumn{3}{|c|}{$\begin{array}{l}\text { Space group: } \\
\text { P63/m \#176; }\end{array}$} \\
\hline & & & \multicolumn{3}{|c|}{$\alpha=90^{\circ}$} \\
\hline $\begin{array}{c}\mathrm{Pb}_{5}\left(\mathrm{VO}_{4}\right)_{3} \mathrm{Cl} \\
{[\mathrm{ICDD} \# 01-073-1732]}\end{array}$ & 10.31 & 7.34 & \multicolumn{3}{|c|}{$\begin{array}{l}\beta=90^{\circ} \\
\gamma=120^{\circ}\end{array}$} \\
\hline
\end{tabular}


662 Table 2. Solution chemistry at equilibrium state calculated by Visual MINTEQ under $66390{ }^{\circ} \mathrm{C}$.

\begin{tabular}{|c|c|c|c|c|c|}
\hline $\begin{array}{l}\mathrm{mol} / \mathrm{L} \\
90^{\circ} \mathrm{C}\end{array}$ & $\begin{array}{l}\text { Deionized } \\
\text { water }\end{array}$ & $\begin{array}{c}0.1 \mathrm{~mol} / \mathrm{L} \\
\mathrm{NaCl}\end{array}$ & $\begin{array}{c}0.1 \mathrm{~mol} / \mathrm{L} \\
\mathrm{Na}_{2} \mathrm{SO}_{4}\end{array}$ & $\begin{array}{c}0.1 \mathrm{~mol} / \mathrm{L} \\
\mathrm{Na}_{2} \mathrm{CO}_{3}\end{array}$ & $\begin{array}{c}0.1 \mathrm{~mol} / \mathrm{L} \\
\mathrm{Na}_{3} \mathrm{PO}_{4}\end{array}$ \\
\hline $\mathrm{pH}$ (unitless) & 6.1 & 6.1 & 6.2 & 10.3 & 10.9 \\
\hline Ionic strength & $2.04 \times 10^{-6}$ & 0.098 & 0.26 & 0.25 & 0.29 \\
\hline Major cation & $\mathrm{H}^{+}$ & $\mathrm{Na}^{+}$ & $\mathrm{Na}^{+}$ & $\mathrm{Na}^{+}$ & $\mathrm{Na}^{+}$ \\
\hline Concentration & $6.52 \times 10^{-7}$ & 0.098 & 0.18 & 0.18 & 0.22 \\
\hline Activity & $6.51 \times 10^{-7}$ & 0.074 & 0.13 & 0.13 & 0.15 \\
\hline $\begin{array}{l}\text { Activity } \\
\text { coefficient }\end{array}$ & 1.00 & 0.76 & 0.72 & 0.72 & 0.68 \\
\hline Major anion & $\mathrm{OH}^{-}$ & $\mathrm{Cl}^{-}$ & $\mathrm{SO}_{4}{ }^{2-}$ & $\mathrm{CO}_{3}{ }^{2-}$ & $\mathrm{PO}_{4}{ }^{3-}$ \\
\hline Concentration & $8.72 \times 10^{-7}$ & 0.098 & 0.079 & 0.069 & 0.012 \\
\hline Activity & $8.70 \times 10^{-7}$ & 0.074 & 0.02 & 0.017 & 0.00049 \\
\hline $\begin{array}{c}\text { Activity } \\
\text { coefficient }\end{array}$ & 1.00 & 0.76 & 0.25 & 0.24 & 0.041 \\
\hline
\end{tabular}

